\title{
The Rogue's Progress: The In-Between World of Vikram Lall
}

\begin{abstract}
M. G. Vassanji's novel The In-Between World of Vikram Lall is presented as an autobiographical narrative recorded by Vikram Lall, a fictional Kenyan Indian, whose life runs parallel with the history of his native country through the second half of the twentieth century. As the eponymous hero confesses in the opening lines of the story: "[He has] the distinction of having been numbered one of Africa's most corrupt men, a cheat of monstrous and reptilian cunning." Using the framework established by Philippe Lejeune in Le Pacte autobiographique (1975), this roguish life appears as a rogue autobiography as well since it "cheats" with the characteristics of the genre. The paper will attempt to show how the novel operates within such a framework and how the usual code is used or misused in the interest of suspense and satire.
\end{abstract}

Key words

M. G. Vassanji; The In-Between World of Vikram Lall; postcolonial corruption; Indians in Africa; National History in fiction; twentieth-century Kenya; (auto) biographical pastiche

The In-Between World of Vikram Lall was published in Canada in 2003. Though the title immediately suggests a biographical story and that of an Indian, Vikram Lall, it also hints at an inherent ambiguity "in-between"; and, interestingly enough, it is this qualifier which actually gives the keynote to the tale that follows. Since the title page clearly states that the author of the narrative is M. G. Vassanji, the first paragraph makes puzzling reading, since it abruptly changes the identity of the narrator, establishes the new one as an unreliable character, and suggests an unexpected geographical setting for the tale. Where one expected an Indian story one is offered instead an African background: "My name is Vikram Lall. I have the 
distinction of having been numbered one of Africa's most corrupt men, a cheat of monstrous and reptilian cunning [...] I head my country's List of Shame." Following this startling introduction comes a first-person narrative which develops as an autobiography, so that the implied judgment of the title "in-between," chosen by Vassanji, is replaced by the avowedly frank narration of the eponymous character: "I do not intend here to defend myself or even seek redemption through confession; I simply crave to tell my story" (Vassanji 2003: 1). But, of course, since Vikram Lall has presented himself as comparable to the serpent of Genesis, a villain of "reptilian cunning," the reader might be left with some doubt as to the veracity of the ensuing story and to the honesty of the relation.

So, from the very opening of the book, the analytical framework of the autobiographical narrative offered by Philippe Lejeune in his seminal study Le Pacte autobiographique (1975) is somewhat shaken. In this work, Lejeune a priori defines an autobiography as: "A retrospective narrative in prose that a person gives of his/her own existence when he/she emphasizes his/her individual life, in particular the history of his/her personality" (14). Several points from this definition are worth considering: first, the retrospective nature of the story that is told, on which the narrator can comment with hindsight; second, the use of prose, which is, of course, common to factual and fictional narratives; third, the identification of the author-narrator with the eponymous "hero," as well as the importance of the evolution of his/her life-story (particularly its events and psychological features).

The analeptic character of the narration enables the author to play freely with the timescale without necessarily having to submit to chronology and linear time. There is also scope for the introduction of relevant external elements and informed commentary, as opposed to diary or memoir writing. The equation "author $=$ narrator $=$ character," which favours what Gérard Genette calls "the autodiegetic narrative voice" (1980: 249-252), together with the emphasis not only on individually eventful factors but also on psychological traits and development that are perceptible through the narration itself, helps to establish the privileged link between the author and his reader - Lejeune's "autobiographical pact," the trust between narrator and reader (French "le narrataire"), implying that the text that is presented as autobiographical is not a fiction (See Rak 2010: 17). ${ }^{1}$ The identity (equation) of the author with the narrator and the character is also ultimately and avowedly the identity (name) of the author. In Vassanji's work, this framework is distorted in a multiplicity of ways, which leads me to consider it a "rogue" autobiography, as we shall later see.

The postmodern, postcolonial (in the literary sense) dimension of the work is, hence, clearly perceptible in the treatment of time, its relation to place and the narrative structure that is chosen for that effect. If we look at the story of the eponymous character, the rogue Vikram Lall, as he progresses through life, the book is divided into four sections that stress various stages of his life. "The Year of Our Loves and Friendships" is followed by "The Year of Her Passion" and "The Years of Betrayal," before the finale "Homecoming." Vikram Lall is a Kenyan Indian, born during Kenya's struggle for independence, and one could 
say that this is his tragedy. Everything starts, as can be expected, from childhood incidents that will bear many consequences, not only for the personalities of the various characters involved in the story, but also for the events of their adult lives. The text, written in the past tense, relates Vikram Lall's life in Africa, mostly Kenya, where he was born and bred and made his career after graduating from university in Tanzania. However, the sequential passage of time is broken in the final part of most chapters in the first section, which abruptly moves from the Mau-Mau-ridden countryside of Nakuru in the mid-1950s to "this clement retreat to which [he] ha[s] withdrawn [him]self, away from the torrid current temper of [his] country" (Vassanji 2003: 3) - in other words, the peaceful suburban area of Toronto at an indefinite date. ${ }^{2}$ This is done through a short paragraph written in the present tense, clearly establishing this point as the wide present of the narration, the time when the narrator, who has described himself in such villainous terms, is actually writing the story he "crave[d]" to tell (2003: 1).

Each of the two subsequent sections follows a similar pattern. Most of the text is the autobiographical narrative of Vikram Lall's personal life and career in now independent Kenya. It reads like an autobiography interspersed with parts of a diary, the latter elusively hinting at some clues towards explaining the current situation. At first sight, two different plot-lines evolve in a parallel fashion, one in Africa, the other in Canada. The two story-lines come together in Section IV, which is also written in the present tense but in a form somewhat echoing stream of consciousness - until the moment the narrator's voice vanishes into the final points de suspension of an open ending, as if the speaking consciousness had suddenly gone mute. The "present" time of the narrative is, thus, located in the final paragraph of the novel, which, despite the significant play with grammatical tenses, does make, of the whole, an analeptic tale. Interestingly enough, the specificity of the last paragraph is stressed by the author through the use of italics. In the in-between world of Vikram Lall, there is no conclusion; everything remains unresolved.

But who is Vikram Lall really? What is this life-story that has been so tantalizingly introduced by its hero? Does it fit the definition of a "rogue's progress"? Although the second meaning of the word rogue is "A dishonest, unprincipled person; a rascal, a scoundrel" (Oxford English Dictionary), which fits the official description of this "Public Enemy Number One"- "a cheat of reptilian cunning" - Vikram Lall declares that, while reading his story, we will find him to be "quite an ordinary man [...] and moderate to a fault" (Vassanji 2003: 1). How can these two statements be reconciled? Shall we find in the narrator's childhood the seeds of both his later personality and the actions that led to his present situation? Vikram Lall belongs to the Indian community of Kenya; as a third-generation immigrant, he is part of the lower-middle class, since his father, a banya, is a grocer in Nakuru catering both to the British colonists and the African workers, as well as to his own community. At first sight, Vikram Lall's childhood would seem banal enough, with its mixture of school, of playing with his sister Deepa and his friends Njoroje (an African) and Bill and Annie (both British, with the latter 
also being his sweetheart), of family parties with grandparents, uncles, aunts and cousins - that is, were it not for the troubled times in which it took place, precisely recorded as 1953 :

It was a world of innocence and play under a guileless constant sun; as well of barbarous cruelty and terror lurking in darkest night; a colonial world of repressive, undignified subjecthood, as also of seductive order and security.

(Vassanji 2003: 5)

As the dramatic political impact of adult activities soon began to impinge on this innocent, childish, multicultural play, Vikram Lall found himself unwittingly embroiled in the events leading to his English friends' massacre by the Mau Mau, and this traumatic experience reverberated throughout his life and relationships with his closer circle. Because he saw and said nothing, this tragedy happened. Indeed, to protect his beloved uncle who was a Mau-Mau supporter, he did not disclose the theft of his own father's revolver, which proved lethal to the Bruce family and, as a consequence of their massacre, led to the death of Njoroje's grandfather and the boy's departure in the care of social services. Somehow the position of the Indians in Kenya had placed him at the crossroads of colonial society, so to speak, wedged between the settlers and the natives. His fate was that of the whole Indian community in Kenya, as Vassanji defines it: "Their dilemma was that they were neither white nor black, and they were both Asian and African" (Vassanji 2010). A conflict of loyalties, too overwhelming for a child, placed him in a position that, if made public, would have already made him appear "deceitful and unreliable" to one or the other of the three communities.

By not speaking out, Vikram Lall destroyed his childhood world and psychologically isolated himself from his family. From then on, the lurking, guilty feeling that he was becoming a solitary creature separated from his herd (which is another sense of the term "rogue") remained with him as a secret wound. While "The Year of Our Loves and Friendships" ends with the recollection of such tragic events, the second section of the novel, "The Year of Her Passion," takes us to the early stages of independent Kenya as well as Vickram Lall's and his contemporaries' adult and professional life in Nairobi. The dilemma evoked by Vassanji is, then, very powerful and intense. Metaphorically, throughout this part it is represented in Deepa's passionate love for Njoroje and the deep suffering that this star-crossed love entails. ${ }^{3}$ Here again, Vikram was the witness of the tearing apart of two people he loves and was the instrument of their separation by society's dictate. He was in-between two worlds - that of his loyalty to his contemporaries Njoroje and Deepa, and of his loyalty to his family, his mother, in particular. Both young men were making their way in the world, Njoroje in the politics of the new country, Vikram as a civil servant in the national railways. Partly through their friendship, Vikram Lall, despite being Indian, which made him suspect and somewhat undesirable in the new African regime, was also progressively and 
unwillingly drawn into the political sphere, since he was posted as assistant to Minister Nderii ${ }^{4}$ and became close to Kenyatta himself.

The third section, "The Years of Betrayal," deals with the apex of Vikram Lall's career. These years of betrayal (Notice the plural, compared with the titles of the previous sections) seem the longest and most important for the autobiographer's purpose. They are those of the betrayal of illusions - illusions of youth for Vikram, Deepa and Njoroje, on a personal level; but also the patriotic illusions of a newly independent country where the ideals of the Fight for Freedom have been betrayed, where the expectations of a whole nation have been turned to ashes due to the greedy cynicism of its elites. The Mau Mau, or freedom fighters, like the Indian business people who are instrumental in economic nation-building, are ousted from the political benefits of independence. Colonial injustice has been replaced by clannish communal injustice and tribal nepotism. During those years, Vikram Lall's love for and loyalty to his country were undeniable, and he was enthusiastically working for the good of his motherland; further, his position also enabled him to protect the interests of the Asian community sorely threatened by the Africanisation policy of the government. His role as mediator ("facilitator," as he calls it) was all the more important because he had direct access to the figurehead of power. However, his role as go-between soon evolved and took him to shadier zones, since foreign companies were trying to bribe him into favouring their contracts with the government, which he rather naively only perceived in retrospect. When instructed by his Minister to exchange increasingly large amounts of foreign currency, provided by Western interests, into Kenyan money - to sustain, he was told, the political actions of the national party - this mission was carried out with no benefit to himself. He just used his connections with the business community of Kenya, whose most affluent members were, indeed, Indians. As all these transactions were presented to him, by the Minister, as being in the national interest, ${ }^{5}$ Vikram Lall was left with no real choice but to comply with his orders, once again in the uncomfortable position of being between two worlds. Indian businessmen, who were easy targets of the Africanisation policy, also could not decline, and this was the price to be paid to avoid seizure of assets and massive expulsions. But, the necessities of official politics, as Vikram discovered only by chance, were just to cover up the ever increasing corruption of the powerful, reaching as high as Kenyatta's own family. So far, Vikram's specific position and the very useful, but dangerous knowledge it entailed had been mainly used by others, be they "perpetually upwardly mobile" African politicians (who desired to get hold of bribe money and launder it into valuable economic assets) or the no less "upwardly mobile" Indian businessmen of Nairobi, which included his relatives (who desired to benefit from insider-trading advantages and to obtain government contracts): "I was their banker of choice, the alchemist who could transmute currencies, the genie who could make monies vanish and produce gold out of thin air" (Vassanji 2003: 394). His powerful position had come, once again, from his silence. By not speaking out, he had been offering a cover up for the corruption and deception that, to his disgust and dismay, had invaded the 
whole of Kenyan political life. After years of aiding the corruption of others in high places whose attitude had abetted his own lack of moral conviction, Vikram Lall was severely hit by the death of Kenyatta, his ultimate protector:

Without my almighty protector, I realized, I was naked, easy picking for any enemy I had casually made on the side. [...] As I had discovered once before, I was an easily disposable commodity. (Vassanji 2003: 390)

As the years of the new regime went by, Vikram Lall, the perennial go-between, had to play a "close game"; but, even if the politicians were different, the old corruption remained, and was even more cynically blatant. The situation changed for the worse when, instead of acting as an intermediary, he decided to play the role of a "front man" in a scam:

The Gemstone Scandal, now synonymous with me and my activities was what put me on that shaming list. But that arrangement of business deals was not even my idea. It simply fell into place like a fortuitous hand at poker. All we had to do, my partners and I, was to pick up the cards and play.

(Vassanji 2003: 406)

Because of international political involvement in the scam, Vikram Lall and his family's lives were at stake. He was left with no other recourse but to speak out, to expose the extent of the corruption he had so far been party to. Such a threat of exposure was, in itself, a death sentence; so, fleeing the country for a secret haven was the only solution. Hence, the Canadian episode, which offered a possible future. The fourth section, "Homecoming," chronologically follows the Canadian episode that is interspersed in the various chapters. It not only takes us back to present-day Nairobi, but is also itself a "homecoming," as the narrator has finally come to terms with his experiences and has decided to speak out, to reveal "his" truth to the Anti-Corruption Commission and bear the consequences:

All the wealth, the money I have made over the past years, I am going to give it up -most of it - part to the Commission and part to a foundation. I will start anew. I will come clear on the Gemstone Scandal. That should satisfy them and the Donors and the World Bank. (Vassanji 2003: 418)

Ultimately I will have my say and make my peace with my world. (431)

However, the interests of many more were at stake. ${ }^{7}$ Once Vikram's intentions were made known to the Commission and the latter agreed to offer an amnesty, the Kenyan government, fearing his revelations, declared the Commission illegal and disbanded it. Vikram's lawyer was then arrested and tortured; Vikram's safehouse was set ablaze; and the narrative voice vanishes with these last words: "Go, run, I will follow you ..." Vikram Lall's fate remains uncertain, hovering between 
life and death, the character still wandering in the in-between world of the title.

For obvious reasons, a straightforward autobiography, as opposed to a biography, traditionally ends before the death of the protagonist. Since Vassanji's work leaves us in doubt, from the point of view of poetics, at least, this provides another questioning as to the author's exact intention with respect to the genre of the text. What in the para-text of the title page was presented as biographical fiction now takes the shape of the autobiographical narrative of a protagonist who shares some features with his creator. Vikram Lall, like Vassanji, is a Kenyan Indian living and writing in Canada. They are also roughly contemporaries in age, so their childhood and years of growing-up were spent in a similar political environment. The similarities stop there, however; the work is not the disguised autobiography of the author, in the way, say, Marcel Proust's Remembrance of Things Past is. What Vassanji has established with his reader is not an autobiographical pact (un pacte autobiographique, as Lejeune defines it), but rather a novelistic pact (un pacte romanesque) in which it is accepted that the autodiegetic narrative is due to a fictional protagonist, the reader agreeing to a Coleridgean "willing suspension of disbelief." Nor, though it uses the form, is it a fictional autobiography, since there is no equation "author = narrator." So, Vassanji is being rather mischievous with his reader and, in this sense, giving us a roguish, somewhat misleading tale. ${ }^{8}$

Indeed, the (auto)biographical nature of the story is neither essential nor necessary to either the gist or even the plotline of the novel. It could just as easily have been written as a third-person heterodiegetic narrative: this somewhat shows that the author's aim was not really to write the biography of a particular, albeit fictional, individual (even if it was the story of his corruption through the circumstances of his life); but rather, to expose by these homodiegetic means the corruption of a system in the aftermath of decolonisation. More than Vikram Lall's destiny, what really echoes in the reader's mind, once this substantial volume has come to its end, is the history of Kenya from the mid-twentieth century to the present.

The real interest of the work is to be found in its socio-political nature rather than in the psychological one that could be expected of an (auto)biography, fictional or not. Vassanji, once again, mischievously clouds the issue. Under the guise of an individual life-story told by its protagonist, Vassanji provides a fictionalised, satirical interpretation of historical events. More than through autodiegetic narrative, it is through diegesis itself that the reader should focus his critical attention. The "world" is, in fact, the real subject of the novel, rather than Vikram Lall. As "Public Enemy Number One," he is, so to speak, a synecdoche for the ambient corruption of his country and, in terms of plot, in a good position to expose the mechanisms of that corruption, a corruption that not only extends to the supposedly great and good (the presidential entourage, as well as Kenyatta himself and his successors), but also to the Western countries and international organisations which had dealings with Kenya. The smug cynicism of foreign agencies and the appetites of African politicians are both denounced in terms of their double-standard discourse, as is their complicit corruption of public life through- 
out the early decades of the postcolonial period. ${ }^{9}$ To satisfy their common greed for Kenya's riches, they stopped at nothing, from subtle bribery to assassination (No less than three of the characters were killed in kidnappings, road accidents, or shooting attacks, and there were at least two attempts on Vikram Lall's life before that final arson-attack). Even the childhood years of innocence were marred by the threat of "barbarous cruelty" and colonial oppression. The picture here painted of contemporary Kenya is grim and bitter; and, through Vikram Lall's strong words against Kenya's current "madness," the reader can feel Vassanji's bitter pain and disillusionment. Even though such feelings are indeed shared by the author and narrator, nevertheless this work essentially deals with "the question of Kenya" rather than the part played by one of its citizens in the history of the nation. More than a biographer (albeit of a fictional protagonist to whom he gives the narrative voice), Vassanji is a political novelist in the satirical and moral vein. The obliqueness of his denunciation, through a character purported to be the epitome of national villainy, yet unruffled by his and others' shady deeds, just reinforces the irony of the denunciation:

The List of Shame has long intrigued her [Seema, his Canadian Indian friend and now lover]. It does sound so dramatically damning. It counts me the most corrupt man in our country, itself ranked one of the most corrupt nations in the world; what does that make of me? (Vassanji 2003: 405)

Finally, Vikram Lall does not actually pretend to exculpate himself, and the picture of such a character drawn by Vassanji raises the issue of collaboration in large-scale, shady, even criminal historical events. How far may one turn a blind eye and participate in reprehensible deeds, even under cover of raison d'Etat (reason of State)?

Together with the autobiographical form, this moralist and satirist has enlisted real characters, such as Ngugi or Kenyatta, as well as fictional ones such as Vikram Lall. Giving precise years for the events purportedly related by the protagonist also contributes to our feeling of their authenticity. In a way, the biographer doubles with the historiographer, in order to give weight to his depiction of a society that is realistically and blatantly close to our own.

Since this pseudo-autobiography operates outside the normal controls of the autobiographical genre, one could say that this "rogue's progress" is related via a "rogue biography" that is playfully meant to mystify the reader about its actual purport.

\section{Notes}

1 The autobiographer makes, whether explicitly or not, a pledge with his reader whereby he shall candidly show himself as he is, "in the whole truth of nature," including his vices, defects and foibles, however difficult this proves to be. Having pledged to tell his story as 
truthfully as memory allows without embellishments (which belong to fiction), in return he expects the reader to pass fair and unbiased judgment.

Though undefined, the date is obviously of much later origin, since the narrator alludes to the visit of the son of Njoroje, his childhood friend.

3 Their relationship will ultimately be used to murder the young political activist.

$4 \quad$ He reflects much later: "I had always been of two minds about him. I liked his wit and his energy. He was smarter than most other politicians. But he was also shamelessly unscrupulous. Mephistopheles-like, he introduced me to the path of power and corruption, and he dropped me when he needed a scapegoat and I was no longer of use" (Vassanji 2003: 390).

"I did not tell about my assignments from my boss Nderi, even though we became very close in those months. I was leading a carefully orchestrated double life, only for the good of the nation" (Vassanji 2003: 301). For a detailed account of the scam and its immediate aftermath, see pp. 406-410. I possessed information that could help indict a platoon of politicians and a hive of senior bureaucrats" (Vassanji 2003: 412). Goldsmith's The Vicar of Wakefield (1766).

\section{References}

Genette, Gérard (1980 [1972]) Narrative Discourse: An Essay in Method. Tran. Jane E. Lewin. Ithaca: Cornell University Press.

Lejeune, Philippe (1975) Le Pacte autobiogaphique. Paris: Seuil.

Rak, Julie (2010) 'Dialogue with the Future: Philippe Lejeune's Method and Theory of Diary'. In: Lejeune, Philippe (2010) On Diary. Ed. Jeremy D. Popkin and Julie Rak. Trans. Katherine Durnin. Manoa: Biographical Research Center, University of Hawaii. 16-26.

Vassanji, M. G. (2010) 'Some Personal Notes on my Books'. M. G. Vassanji. 5 November 2010. $<$ http://www.mgvassanji.com>.

Vassanji, M. G. (2003) The In-between World of Vikram Lall. Canada: Doubleday.

Evelyne Hanquart-Turner is Emerita Professor of English at the University of Paris Est-Créteil and Member of Darwin College, Cambridge. She studied and taught at the Sorbonne and Cambridge before her election to a chair at the University of Paris Est-Créteil, where she founded and directed the Research Institute IMAGER (E.A. 3958). She has published extensively in French and in English on E. M. Forster, Rudyard Kipling, the British Raj, and contemporary Indian writers in English such as Anita Desai, Kamala Markandaya, Amit Chaudhuri, Anita Nair, Shashi Tharoor and Amitav Ghosh. She is currently working on translations of Indian short stories into French and on a book on Time and History in Indo-English fiction.

Address: Prof. Evelyne Hanquart-Turner, Université Paris-Est Créteil Val de Marne, Faculté des lettres, langues et sciences humaines, département d'anglais, 61, avenue du Général de Gaulle, 94010 Créteil, France. [email: ehturner@hotmail.fr] 
